\title{
EXAMINING THE EFFICIENCY OF MECHANIC/ENZYMATIC PRETREATMENTS IN MICRO/NANOFIBRILLATED CELLULOSE PRODUCTION
}

\author{
Ayhan Tozluoğlulı, Bayram Poyraz', Zeki Candan ${ }^{3}$
}

\begin{abstract}
There is still a need to improve the production sequences of micro fibrillated and nano fibrillated celluloses to obtain more economic and better quality products. The aim of this study was to improve the production efficiency and quality of micro fibrillated and nano fibrillated celluloses by examining the enzyme (xylanase endo-1,4-) employed in pretreatment sequences. Fairly homogeneous nano fibrillated cellulose with a width of $35 \pm 12 \mathrm{~nm}$ was produced in this study. Sequences employed to produce micro fibrillated and nano fibrillated celluloses decreased the cellulose crystallinity of bleached kraft pulp and lower total crystalline index and lateral order index values were observed for micro fibrillated and nano fibrillated celluloses in FTIR examinations. Lower crystallinities were also defined by ${ }^{13} \mathrm{C}-\mathrm{NMR}$ $(46,2 \mathrm{ppm})$ which was substantiated with C6 peaks in the amorphous domain. Sequences to produce micro fibrillated and nano fibrillated celluloses resulted in shorter fiber dimensions with less ordered cellulose structure leading lower thermal degradation that reveal main polymer chain source from cellulose units. Dynamic mechanical thermal analysis results showed that the initial and maximum storage modulus of the nano fibrillated and micro fibrillated celluloses films were improved by $114 \%$ and $101 \%$, respectively. The storage modulus of micro fibrillated and nano fibrillated celluloses films were $4,96 \mathrm{GPa}$ and $2,66 \mathrm{GPa}$ at temperature of $235^{\circ} \mathrm{C}$, respectively.
\end{abstract}

Keywords: Biofilm, chemical characterization, Kraft pulp, homogenization, thermomechanical characterization.

\section{INTRODUCTION}

Cellulose is one of the most abundant, renewable and biodegradable natural polymers (Habibi et al. 2010). It consists of D-glucose subunits which are linked together by $-1,4$ glycosidic bonds. Intra and inter-molecular bonds in cellulose constructs microfibrils that are packed side by side and generates microfibril bundles. Biopolymers have been progressively processed in nanotech by methods of homogenization, micro fluidization, micro grinding, cryocrushing, acid hydrolysis (Siro and Plackett 2010) and enzyme treatments (Lavoine et al. 2012). These processes improve the mechanical and thermal properties of the materials and make them suitable for several industrial applications; papermaking, additives, thickeners, stabilizers, fillers, pharmaceutics and etc. (Syverud and Stenius 2008, Hettrich et al. 2014).

In nanoscale cellulose production, the main component resisting the separation process is lignin. Lignin acts as a protective barrier and obstacles the cell permeability causing insignificant cell destruction. Therefore, lignin removal is necessary for efficient processes (Pérez et al. 2002). The other cell wall component, essence of hemicelluloses in the structure also positively affects the production

\footnotetext{
${ }^{1}$ Faculty of Forestry, Forest Products Engineering Department, Duzce University, Duzce, Turkey.

${ }^{2}$ Faculty of Technology, Department of Civil Engineering, Duzce University, Duzce, Turkey.

${ }^{3}$ Faculty of Forestry, Forest Product Engineering Department, Istanbul University, Istanbul, Turkey.

"Corresponding author: ayhantozluoglu@duzce.edu.tr

Received: 17.01.2017 Accepted: 16.10.2017
} 
efficiency (Agbor et al. 2011). On the other hand, physcochemical factors of crsytallinity and packed structure affect the production efficiency (Khalil et al. 2012). Packed cellulose is insoluble in water as the hydroxyl groups are bonded to each other. In order to improve the production efficiency, the supramolecular structure of cellulose must be disrupted into amorphous phases.

One of the most applied method to produce micro/nano fibrillated cellulose (MFC/NFC) with a high yield is mechanical treatment. However, the method requires vast amount of energy (Spence et al. 2011). To overcome the deficiencies of the above explained method, enzymatic pretreatments along with the mechanical treatment applied to reduce the consumed energy ( $\mathrm{Li}$ et al. 2011). For this reason, generally, endoglucanases act to cleave the internal bonds (e.g., noncovalent interaction) present in the amorphous structure of cellulose. Exoglucanases/cellobiohydrolases attack the ends of the cellulose chains which are generated by the endoglucanases. Subsequently, the shorter cellulose chains are further hydrolyzed by cellobiases/beta-glucosidases into nanocellulose or even a glucose product (Lee et al. 2014).

In this parallel, Pääkko et al. (2007) demonstrated a combination of high shear pressure force and mild enzymatic hydrolysis (monocomponent endoglucanase) by using sulfite pulp to produce MFC by maintaining high aspect ratio with well controlled diameter. In addition, there are number of studies revealing properties of MFC/NFC suspensions and their films (Saito et al. 2007, Bismarck et al. 2005, Dri et al. 2013, Viana et al. 2016). Besides, new trend related to MFC/NFC is of their composites with inorganic/organic polymers (Kord et al. 2016, Poyraz et al. 2017).

There is a gap that explains relations between chemical structure and physical/thermal $/$ mechanical properties in the literature. For that purpose, detailed chemical, rheological and thermal characterization of MFC/NFC suspensions as well as morphology and dynamic mechanical results were studied in this study.

\section{MATERIALS AND METHODS}

\section{Materials}

For this study, freshly cut logs of a 16-year-old river red gum tree (Eucalyptus camaldulensis) brought from Tarsus, Turkey, was used as raw material. The bark and cambium were carefully removed and the logs were reduced to chips suitable for the subsequent kraft pulping operations. The chips were air-dried and screened to establish a uniform size throughout pulping.

The enzyme employed to break down the cellulose and hemicellulose structures was xylanase endo-1,4- (Novozymes, Bagsvaerd, Denmark).

\section{Methods}

\section{Pulping and bleaching}

Kraft pulp was produced using $500 \mathrm{~g}$ of chips (o.d.). The cook was made in a $10 \mathrm{~L}$ rotating digester (Uniterm Rotary Digester, Uniterm Lab.) at $150^{\circ} \mathrm{C}$ for 150 min after reaching the maximum temperature in 30 min. The calculated $\mathrm{H}$-factor was 410 . The cook was achieved at $18 \%$ active alkali and $28 \%$ sulphidity charges, and the liquor-to-wood ratio $(\mathrm{L} / \mathrm{kg})$ was $5: 1$. The produced pulp was disintegrated and washed with hot tap water, and then screened using a flat laboratory screen (Somerville Flat Screen, Techlab Systems) with a slot width of $0,15 \mathrm{~mm}$ (Tappi T275). The pulp yield (screened/unscreened) and rejects were determined according to Tappi T210 via gravimetric measurements in the laboratory environment.

The pulp was bleached using Elemental Chlorine Free (ECF) processes (ODEP: oxygen-chlorine dioxide-alkaline-peroxide). Oxygen $\left(\mathrm{O}_{2}\right)$ bleaching was conducted in a digester using $2 \% \mathrm{NaOH}$ (as $\mathrm{Na}_{2} \mathrm{O}$-o.d. pulp) and $0,5 \% \mathrm{MgSO}_{4}$ (as carbohydrate stabilizer-o.d. pulp) at a pressure of $6 \mathrm{kgf} \mathrm{cm}^{-2}$ $\left(90^{\circ} \mathrm{C}\right.$ for $\left.60 \mathrm{~min}\right)$. The consistency was $10 \%$. The chlorine dioxide (D) bleaching was performed in a 
plastic bag placed in a water bath (GFL 1023 Water Bath, GFL Lab.) $\left(60{ }^{\circ} \mathrm{C}\right.$ for $\left.60 \mathrm{~min}\right)$ and each pulp $\left(10 \mathrm{~g}\right.$, o.d.) was treated with $100 \mathrm{~mL} \mathrm{ClO} 2(1 \%)$ consisting of $3 \mathrm{~mL} \mathrm{H}_{2} \mathrm{SO}_{4}(98 \%)$ solution. The alkaline extraction (E) was also performed in a water bath at $60^{\circ} \mathrm{C}$ for $60 \mathrm{~min}$ and each pulp $(10 \mathrm{~g}$, o.d.) was treated with $100 \mathrm{~mL} \mathrm{NaOH}$ solution $(2 \%)$. The hydrogen peroxide bleaching $(\mathrm{P})$ was conducted at $10 \%$ pulp consistency using $4 \% \mathrm{H}_{2} \mathrm{O}_{2}, 0,5 \% \mathrm{Na}_{2} \mathrm{SiO}_{3}$ (as hydrogen peroxide stabilizer), $0,1 \% \mathrm{MgSO}_{4}$ and $1,5 \% \mathrm{NaOH}$ (o.d. pulp). The process was carried out at $105^{\circ} \mathrm{C}$ for $120 \mathrm{~min}$ in a digester. After each bleaching operation, the pulps were washed with water, squeezed and crumbled.

The kappa number (Tappi T236) and viscosity (degree of polymerization of the cellulose) (SCAN $\mathrm{cm}$ 15-62) of the pulps were then determined.

\section{Gel preparation}

The cell wall delamination of the bleached kraft pulp was accomplished in four stages: mechanical refining, enzymatic pretreatments, second mechanical refining, and homogenizing. The bleached kraft pulp was first mechanically refined $(2 \% \mathrm{w} / \mathrm{w}$ ) for 10 min using a Waring blender (NuBlend Commercial Blender, Waring Commercial) to reach $30{ }^{\circ} \mathrm{SR}$ (Chang et al. 2012). The power input was $1,9 \mathrm{~A}$ at $115 \mathrm{~V}$. The process was paused for 5 min to allow the material to cool down to approximately room temperature. The freeness of the pulp was measured using a Schopper Riegler device (SR/P Schopper Riegler, Thwing-Albert Instrument Company) (ISO Standard method 5267-1).

Refined materials (50 g o.d. pulp) were enzymatically hydrolyzed using xylanase endo-1,4- for concentrations of 25,100 and $250 \mathrm{AXU} / \mathrm{g}$ at $2 \%$ solid loading in $2,5 \mathrm{~L}$ of phosphate buffer at $\mathrm{pH}$ 7,0. The phosphate buffer used in the enzymatic pretreatments was prepared from $11 \mathrm{mM} \mathrm{KH_{2 }} \mathrm{PO}_{4}$ and $9 \mathrm{mM} \mathrm{Na}_{2} \mathrm{HPO}_{4}$. The enzyme reactions were accomplished in an incubator (Incubator ES-20, Biosan Lab.) at $50{ }^{\circ} \mathrm{C}$ for $2 \mathrm{~h}$. The samples were mixed manually every $30 \mathrm{~min}$. At the end of the pretreatment, the samples were washed with deionized water and put into boiling water for $30 \mathrm{~min}$ to stop the enzymatic activity. Then the samples were again washed with deionized water. The highest ratio of removed glucan to xylan was obtained with enzyme concentration of $100 \mathrm{AXU} / \mathrm{g}(0,84: 25$ AXU/g; 0,99: $100 \mathrm{AXU} / \mathrm{g} ; 0,77: 250 \mathrm{AXU} / \mathrm{g}$ ). For that purpose the sample with the highest amount of xylan was selected for further analysis.

The enzymatically pretreated sample was then refined again using a Waring blender (NuBlend Commercial Blender, Waring Commercial) (Chang et al. 2012), to reach $90^{\circ} \mathrm{SR}$. To prevent a bacterial growth in the material $0,4 \mu \mathrm{L} / \mathrm{mL}$ of a microbicide (5-chloro-2-methyl-4-isothiazolin-3-one) was added to the slurry.

In the MFC and NFC production stage, the sample was passed through a high-pressure fluidizer $(2 \% \mathrm{w} / \mathrm{w})$ (Microfluidizer M-110Y, Microfluidics Corp.). For the MFC production, the sample was passed one time through a Z-shaped chamber with a diameter of $200 \mu \mathrm{m}(14000 \mathrm{psi})$. For the NFC production, the sample was passed once through a Z-shaped chamber with a diameter of $200 \mu \mathrm{m}$ (14000 psi) and then passed five times through a chamber with a diameter of $100 \mu \mathrm{m}$ (24000 psi).

\section{Film manufacturing procedure}

For MFC or NFC film manufacturing, the MFC or NFC was stirred for $1 \mathrm{~h}$ at room temperature to ensure homogeneous consistency. The MFC or NFC suspension was poured onto a glass plate. The materials were placed in a dryer to evaporate water at $60^{\circ} \mathrm{C}$ for overnight. The NFC or MFC films were peeled off from the plate and kept at room temperature for 24 hours before the dynamic mechanical thermal analysis (DMTA).

\section{Analytical methods}

HPLC (High-performance liquid chromatography) Analysis: The sugar and the lignin contents of the samples were determined by Laboratory Analytical Procedures (LAP) from the National Renewable Energy Laboratory (NREL) (Sluiter et al. 2004). The sugar contents were analyzed using the HPLC (Agilent 1200 System, Agilent Tech.) equipped with a Shodex SP0810 column (mobile phase: HPLC 
grade water- $0,2 \mu \mathrm{m}$ filtered and degassed; injection volume: $20 \mu \mathrm{L}$; flow rate: $0,6 \mathrm{ml} / \mathrm{min}$; column temperature: $80{ }^{\circ} \mathrm{C}$ ) and a refractive index detector. The acid-insoluble and acid-soluble lignin were determined, respectively, by weighing and by the adsorption at $320 \mathrm{~nm}$ against a deionized water blank.

The reduction in lignin was calculated based on the initial dry weight of the lignin in the both chip and bleached kraft pulp (LU) and the dry weight of the lignin in the remaining solids after the pulping, bleaching, refining, enzymatic hydrolysis and homogenizing treatments (LP). The percentage of lignin reduction was calculated with the following Equation 1:

$$
\text { The percentage of lignin reduction }=\frac{L U-L P}{L U} \times 100
$$

The solubilization of xylan and glucan during the treatments was also calculated in the same manner.

Furthermore, the percentage of solids recovered was calculated on an oven-dry basis as follow Equation 2:

$$
\text { The percentage of solids recovered }=\frac{W 2}{W 1} \times 100
$$

where $\mathrm{W} 1$ is the dry weight of the whole biomass before treatment (g), and W2 is the dry weight of the treated material $(\mathrm{g})$.

FTIR (Fourier transform infrared) Spectroscopy: The IR spectra were taken via an attenuated total reflectance (ATR)-FTIR device (Shimadzu IR Prestige-21, Shimadzu Corp.). Sample suspensions of $0,5 \mathrm{ml}$ were prepared in a concentration of $2 \%(\mathrm{w} / \mathrm{w})$. The samples were gently dropped in a diamond attachment using an automatic pipette $(0,1-1 \mathrm{ml})$. In order to elucidate molecular vibration signals in the range of $4000-600 \mathrm{~cm}^{-1}, 20$ scans with a resolution of $4 \mathrm{~cm}^{-1}$ were taken.

\section{${ }^{13} \mathrm{C}$ CP/MAS NMR (Cross Polarization Magic Angle Spinning Nuclear Magnetic Resonance) Spectroscopy:}

The solid state ${ }^{13} \mathrm{C} \mathrm{CP} / \mathrm{MAS}$ NMR spectra of the samples were recorded using an Advance III 300MHz NMR instrument (Bruker Corp.). The operating frequency was fixed at $75385 \mathrm{MHz}$. A double air-bearing probe and a zirconium oxide rotor $(4 \mathrm{~mm})$ were used in the analysis. The MAS rate was $8500 \mathrm{~Hz}$. A CP pulse was ramped at a contact pulse of $100 \mu \mathrm{s}$ with the rotation of $4 \mu \mathrm{s}$ proton at $90^{\circ}$ pulse $\left(294,8^{\circ} \mathrm{K}\right)$. The delay between repetitions was $2,5 \mathrm{~s}$.

\section{Rheological Measurements}

In order to determine the rheological properties of the samples, a RST-CPS Rheometer (Brookfield Corp.) was used. The measurements were made at the $37,5 \mathrm{~mm}$ diameter cone-plate and the $25 \mathrm{~mm}$ diameter parallel plate. The gap was fixed at $1 \mathrm{~mm}$. Before the measurements, the shearing was applied to the materials at $20000 \mathrm{rpm}$ for $2 \mathrm{~min}$ (IKA T18 homogenizer, IKA Lab.) to disrupt any flocculated aggregates and the samples were then allowed to rest for $3 \mathrm{~min}$.

\section{SEM (Scanning Electron Microscopy)}

The morphological properties of the samples were analyzed by taking SEM (FEI Quanta FEG 250, FEI Corp.) images. The samples were first dried at $105^{\circ} \mathrm{C}$ overnight, and then coated up to $5 \mathrm{~nm}$ with a gold-palladium composite. Pictures were taken for all samples at $1-15 \mathrm{kV}$ using a field emission gun equipped with a compacted secondary electron detector. Scales were selected as $100 \mu \mathrm{m}$ for fiber materials and 1 and $100 \mu \mathrm{m}$ for MFC and NFC. In addition, SEM analyses were carried out for MFC or NFC films. 


\section{Thermal Analysis}

The thermal properties of the materials were examined using thermogravimetric analysis (TGA). For the TGA, a Shimadzu DTG 60 (Shimadzu Corp.) equipped with a thermal analysis data station was utilized. The material samples were first dried at room temperature overnight. Approximately $5 \mathrm{mg}$ of the material was placed in a platinum pan and heated from room temperature to $650{ }^{\circ} \mathrm{C}$ at a rate of 20 ${ }^{\circ} \mathrm{C} / \mathrm{min}$. Measurements were carried out under nitrogen flow $\left(75 \mathrm{~mL} \mathrm{~min}^{-1}\right)$. The mass of the material was recorded as a function of the temperature.

\section{Dynamic Mechanical Thermal Analysis (DMTA) of Nanofilms and Microfilms}

DMTA tests were carried out to obtain thermo-mechanical characteristics (storage modulus) of the produced MFC and NFC films. The test was performed in tension mode at a controlled heating rate of $5^{\circ} \mathrm{C} / \mathrm{min}$. The temperature raised from $30^{\circ} \mathrm{C}$ to $250^{\circ} \mathrm{C}$ at an oscillatory frequency of $1 \mathrm{~Hz}$.

\section{RESULTS}

\section{Yield, kappa and viscosity (degree of polymerization of the cellulose) analyses}

The screened yield of kraft pulp for the eucalyptus was $45,6 \%$ (o.d. chip) and a very small amount of the reject obtained ( $0,03 \%$ o.d. pulp). The kappa number and viscosity were 18,4 and 10,2 $\mathrm{cP}$ respectively (Table 1). Bleaching sequences diminished the kappa number and viscosity and the decrease of kappa number and viscosity for the final bleached pulp were $83,6 \%$ and $47,1 \%$ respectively.

Table 1. Yield, kappa and viscosity values of kraft pulp after each bleaching stage.

\begin{tabular}{|l|c|c|c|}
\hline Bleaching stages & Total Yield, \% & Kappa & Viscosity, cP \\
\hline Kraft & $45,7 \pm 0,46$ & $18,4 \pm 0,15$ & $10,2 \pm 0,38$ \\
\hline Kraft-O & $44,8 \pm 0,17$ & $10,4 \pm 0,00$ & $9,50 \pm 0,26$ \\
\hline Kraft-O-D & $44,7 \pm 0,22$ & $4,16 \pm 0,00$ & $5,15 \pm 0,21$ \\
\hline Kraft-O-D-E & $41,9 \pm 0,34$ & $3,59 \pm 0,09$ & $5,60 \pm 0,10$ \\
\hline Kraft-O-D-E-P & $41,5 \pm 0,26$ & $3,02 \pm 0,01$ & $5,40 \pm 0,10$ \\
\hline
\end{tabular}

\section{Chemical properties}

\section{HPLC analyses}

The chemical composition of wood and un/bleached pulps were given in Table 2. The HPLC analyses showed that the total carbohydrate of E. camaldulensis was $49,3 \%$ (o.d. chip). Glucan, the major cell wall component, made up 40,0\% (o.d. chip), and xylan, the major hemicellulose constituent, was $8,67 \%$ (o.d. chip). Mannan, arabinan and galactan accounted for only $0,62 \%$ (o.d. chip). The total lignin (acid insoluble/soluble) was 28,3\% (o.d. chip) (Table 2). The glucan contents of un/bleached kraft pulps were 61,8 and $66,3 \%$ and the xylan contents of un/bleached kraft pulps were 15,3 and $14,3 \%(\mathrm{w} / \mathrm{w})$, respectively. 
Table 2. Chemical composition of pulps after pulping and bleaching.

\begin{tabular}{|l|c|c|c|}
\hline \multicolumn{4}{|c|}{ Chemical Components (\%) } \\
\hline Glucan & Chips & Unbleached Kraft & Kraft (ODEP) \\
\hline Xylan & $40,0 \pm 1,53$ & $61,8 \pm 2,04$ & $66,3 \pm 0,90$ \\
\hline Galactan & $8,67 \pm 0,19$ & $15,3 \pm 0,65$ & $14,3 \pm 0,85$ \\
\hline Mannan+Arabinan & $0,18 \pm 0,14$ & - & - \\
\hline Acid Insoluble Lignin (AIL) & $0,44 \pm 0,20$ & $0,33 \pm 0,00$ & $0,67 \pm 0,00$ \\
\hline Acid Soluble Lignin (ASL) & $27,6 \pm 0,99$ & $1,98 \pm 0,54$ & $0,40 \pm 0,09$ \\
\hline \multicolumn{4}{|c|}{ \% removed material (o.d. chip) } \\
\hline Total material & $0,74 \pm 0,01$ & $1,05 \pm 0,02$ & $1,16 \pm 0,41$ \\
\hline Glucan & - & 54,4 & 58,5 \\
\hline Xylan & - & 29,5 & 31,2 \\
\hline Total lignin & - & 19,5 & 31,6 \\
\hline
\end{tabular}

Alterations in chemical compositions of bleached kraft pulp after mechanical and enzymatical pretreatments and then homogenization were shown in Table 3. Mechanical pretreatment diminished the glucan $(1,80 \%$ o.d. bleached pulp) and xylan $(0,20 \%$ o.d. bleached pulp) contents. Varying enzyme concentrations applied in this study resulted in $65 \%(25 \mathrm{AXU} / \mathrm{g})$ to $66,8 \%(100 \mathrm{AXU} / \mathrm{g})(\mathrm{w} / \mathrm{w})$ of glucan and $13,8 \%(250 \mathrm{AXU} / \mathrm{g})$ to $14,4 \%(100 \mathrm{AXU} / \mathrm{g})(\mathrm{w} / \mathrm{w})$ of xylan contents. The studied enzyme concentration for further process was determined regarding the removal of glucan to xylan ratio. The determined concentration for further process was $100 \mathrm{AXU} / \mathrm{g}$. This sample was mechanically pretreated again and the obtained sample had $66,3 \%$ of glucan and $14 \%$ xylan $(\mathrm{w} / \mathrm{w})$ in the structure. The samples were then homogenized and MFC and NFC were produced. Results showed that MFC and NFC had 66,3 and $65,9 \%(\mathrm{w} / \mathrm{w})$ of glucan and 13,9 and $13,8 \%(\mathrm{w} / \mathrm{w})$ of xylan in the structure, respectively.

Table 3. Changes in chemical components of kraft pulp after mechanic/enzymatic pretreatments and homogenization.

\begin{tabular}{|c|c|c|c|c|c|c|c|}
\hline \multirow{2}{*}{ Chemical Components ( $\%$ ) } & \multirow{2}{*}{$\begin{array}{l}\text { Finst } \\
\text { refining }\end{array}$} & \multicolumn{3}{|c|}{$\begin{array}{c}\text { Encymatic treatment (Concentrations, } \\
\text { AXU/g) }\end{array}$} & \multicolumn{3}{|c|}{$\begin{array}{l}\text { The enzyme treated sample (Concentration } \\
\text { of } 100 \mathrm{AXU} / \mathrm{g})\end{array}$} \\
\hline & & 25 & 100 & 250 & $\begin{array}{c}\text { Second } \\
\text { Refining }\end{array}$ & MFC & NFC \\
\hline Glucan & $65,7=0,07$ & $65,0=0,02$ & $66,8=0,91$ & $65,8=0,08$ & $66,3=0,56$ & $66,3=0,05$ & $65,9=0,01$ \\
\hline Xylan & $14,5=0,24$ & $13,9=0,12$ & $14,4=0,04$ & $13,8=0,11$ & $14,0=0,10$ & $13,9=0,19$ & $13,8=0,82$ \\
\hline \multicolumn{8}{|c|}{$\%$ removed material (o.d. chip) } \\
\hline Glucan & 33,0 & 34,2 & 34,9 & 35,8 & 35,9 & 35,9 & 36,2 \\
\hline Xylan & 31,8 & 35,1 & 35,2 & 37,5 & 37,5 & 38,0 & 38,4 \\
\hline \multicolumn{8}{|c|}{ \% removed material (o.d. bleached lraft pulp) } \\
\hline $\begin{array}{l}\text { Glucan } \\
\text { Xvlan }\end{array}$ & $\begin{array}{l}2,56 \\
0,31\end{array}$ & $\begin{array}{l}4,32 \\
5,14 \\
\end{array}$ & $\begin{array}{l}5,32 \\
5,37 \\
\end{array}$ & $\begin{array}{l}6,73 \\
8,65 \\
\end{array}$ & $\begin{array}{l}6,75 \\
8,70\end{array}$ & $\begin{array}{l}6,75 \\
9,36\end{array}$ & $\begin{array}{l}7,31 \\
10,0\end{array}$ \\
\hline
\end{tabular}

\section{FTIR analyses}

The molecular interactions of bleached kraft pulp, MFC and NFC produced in this study were investigated by FTIR (Figure 1). In the spectra, the slightly broad $\mathrm{O}-\mathrm{H}$ stretching peaks observed at $3328 \mathrm{~cm}^{-1}$ matched to the free $\mathrm{OH}$ groups of the cellulose molecules corresponding to intra and intermolecular H-bonds. O-H in-plane bending vibration was additionally observed at $1336 \mathrm{~cm}^{-1}$. 


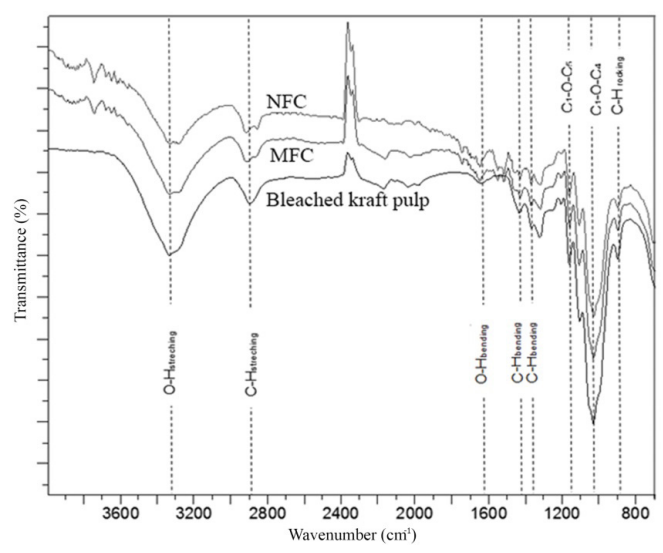

Figure 1. FT-IR spectras for bleached kraft pulp, MFC and NFC.

Lignin peaks, $1740 \mathrm{~cm}^{-1}$ (carbonyl), $1509 \mathrm{~cm}^{-1}$ (aromatic $\mathrm{C}=\mathrm{C}$ ring deformation) and $1463 \mathrm{~cm}^{-1}$ (C-H deformation), were not observed in this study. Peaks at about $1163 \mathrm{~cm}^{-1}$ are related to $\mathrm{C}_{1}-\mathrm{O}-\mathrm{C}_{5}$ asymmetric bridge stretching and the peaks reveal the ether linkage in the pyronose rings. In addition, the peak intensity of the glycosidic deformation or pyranose ring skeletal stretching was observed at $1033 \mathrm{~cm}^{-1}\left(\mathrm{C}_{1}-\mathrm{O}-\mathrm{C}_{4}\right)$.

The total crystalline index (TCI) (A1378/A2900) of the samples were calculated regarding the ratio between $\mathrm{CH}_{2}$ asymmetric stretching vibration peaks $\left(2900 \mathrm{~cm}^{-1}\right)$ and $\mathrm{C}-\mathrm{H}$ asymmetric deformation vibration $\left(1378 \mathrm{~cm}^{-1}\right)$. In addition, Lateral Order Index (LOI) (A1437/A899) value indicating the $\beta$-glycosidic linkages between glucose units was calculated regarding the intensity ratio between inplane scissoring (symmetric bending) $\left(1437 \mathrm{~cm}^{-1}\right)$ and $\mathrm{C}-\mathrm{H}$ rocking $\left(897 \mathrm{~cm}^{-1}\right)$. The calculated values of TCI and LOI were shown in Table 4.

Table 4. Total crsytalline ratio and lateral order index obtained from the FT-IR analysis of cellulose samples studied.

\begin{tabular}{|c|c|c|}
\hline & $\begin{array}{c}\text { TCI } \\
\left(1378 \mathrm{~cm}^{-1} / 2900 \mathrm{~cm}^{-1}\right)\end{array}$ & $\begin{array}{c}\text { LOI } \\
\left(1437 \mathrm{~cm}^{-1} / 899 \mathrm{~cm}^{-1}\right)\end{array}$ \\
\hline Bleached Kraft Pulp & $0,488 \pm 0,011$ & $1,638 \pm 0,021$ \\
\hline MFC & $0,462 \pm 0,008$ & $1,592 \pm 0,018$ \\
\hline NFC & $0,441 \pm 0,007$ & $1,571 \pm 0,012$ \\
\hline
\end{tabular}

\section{${ }^{13}$ C-NMR analyses}

The chemical structures of the samples were analyzed by CP/MAS ${ }^{13} \mathrm{C}-\mathrm{NMR}$ (Figure 2). Results showed that the intensity of the peaks decreased from bleached kraft pulp to MFC and then to NFC. 


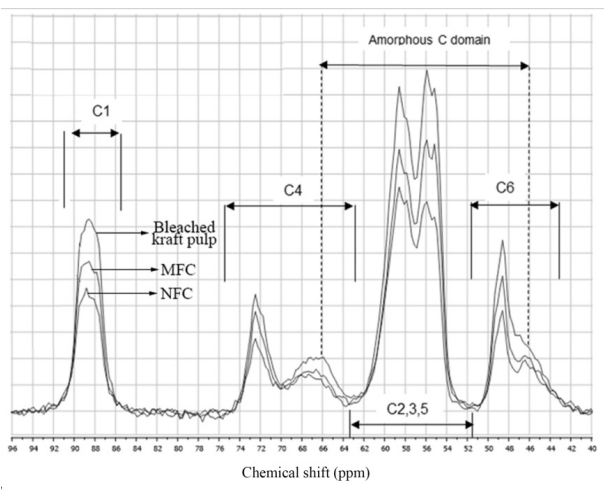

Figure 2. ${ }^{13} \mathrm{C}-\mathrm{NMR}$ spectra for bleached kraft pulp, MFC and NFC.

The spectroscopy used to distinguish between crystalline (ordered) and amorphous (less-ordered) cellulose based on the chemical shifts and clusters in C4 and C6 peaks. Sharp signals imply well ordered (crystalline) regions whereas broad signals show less ordered regions (amorphous). The left domains of both $\mathrm{C} 4$ and $\mathrm{C} 6$ peaks displayed the crystalline character whereas the right domains of both showed the amorphous character (Figure 2). The most intense peaks were related to C2, C3 and C5 positions, which were observed at around 61-53 ppm.

\section{Rheological properties}

The rheological properties of bio-based suspensions are of vital importance for the prediction of composites performance for the potential end applications. The viscosity was plotted as a function of the shear rate for bleached kraft pulp, MFC and NFC samples (Figure 3). The produced NFC had the lowest viscosity.

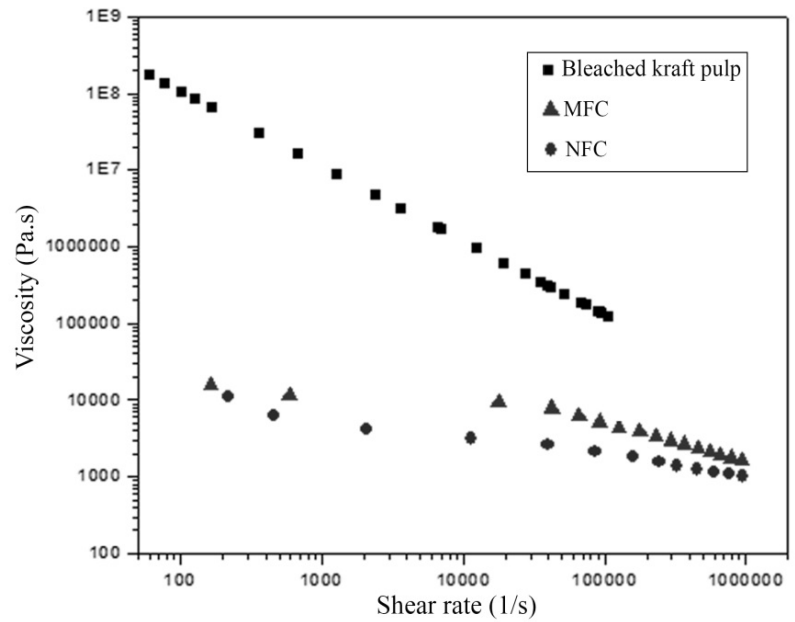

Figure 3. Viscosity as a function of the shear rate for bleached kraft pulp and MFC-NFC materials.

\section{Morphological (Structural) properties}

Figure 4 shows the SEM images of bleached kraft pulp (Figure 4a), MFC (Figure 4b) and NFC (Figure 4c) samples. The fiber width of the bleached pulp was in micron size. The SEM images of MFC and NFC was pictured at two different scales $(100 \mu \mathrm{m}$ and $1 \mu \mathrm{m})$. MFC samples pictured at the $100 \mu \mathrm{m}$ scale showed some micron-wide fibers. On the other hand, some nanofibrils were apparent in images taken at $1 \mu \mathrm{m}$. The NFC sample examined at the $100 \mu \mathrm{m}$ scale had none micron width fibers. These 
indicated that the method utilized in this study resulted in fairly homogeneous NFC production. The generated nanofibers had a rod-like structure with an average length $(3820 \pm 170 \mathrm{~nm})$ and width $(35 \pm$ $12 \mathrm{~nm}$ ). The average aspect ratio of NFC was $115 \pm 35$.

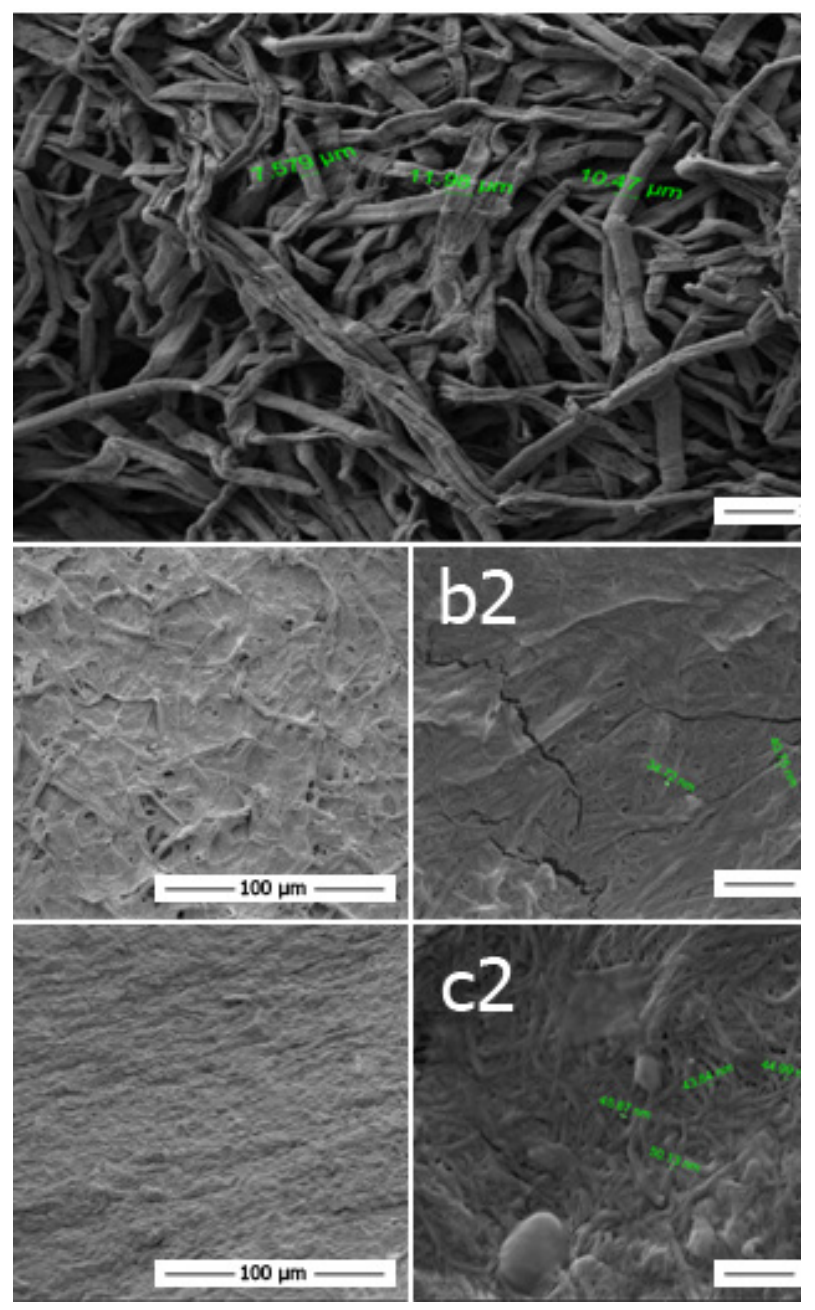

Figure 4. SEM images: (a) bleached kraft pulp, (b1-2) MFC and (c1-2) NFC materials.

\section{Thermal analysis}

The TGA curves of the bleached kraft pulp, MFC and NFC were given in Figure 5. All analyzed samples were exposed to two-step degradation processes. Initial weight losses was started at $25^{\circ} \mathrm{C}$ and then preceded up to $180^{\circ} \mathrm{C}$. Bleached kraft pulp lost the highest moisture compared to NFC and MFC.

A significant weight loss was observed at about $320{ }^{\circ} \mathrm{C}-400{ }^{\circ} \mathrm{C}$. The NFC showed the lowest thermal decomposition and thermal stability $\left(318^{\circ} \mathrm{C}\right)$ as well as broader degradation range compared to bleached kraft pulp $\left(340^{\circ} \mathrm{C}\right)$ and $\operatorname{MFC}\left(328^{\circ} \mathrm{C}\right)$. 


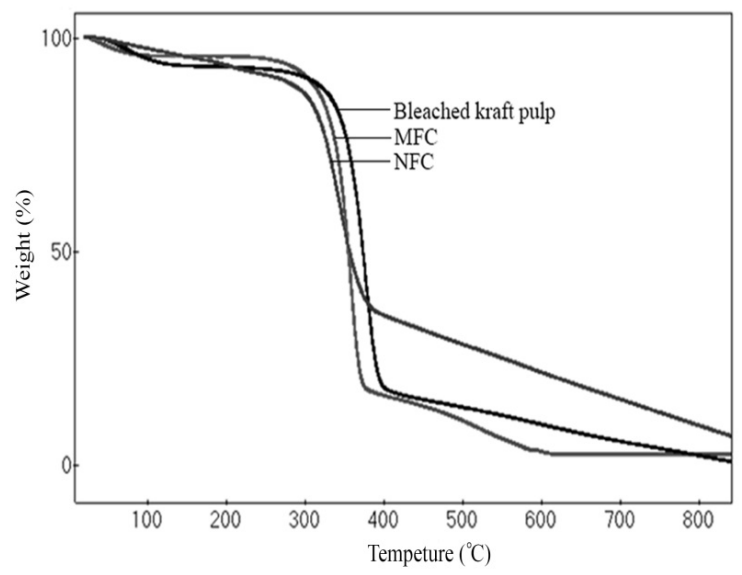

Figure 5. TGA thermograms for bleached kraft pulp, MFC and NFC.

\section{Dynamic mechanical thermal analysis (DMTA) of nano/micro films}

The films of MFC and NFC were shown in Figure 6. DMTA showed that the storage modulus values of the NFC and MFC films increased with increasing temperature from $30{ }^{\circ} \mathrm{C}$ to $84{ }^{\circ} \mathrm{C}$ and 30 ${ }^{\circ} \mathrm{C}$ to $104{ }^{\circ} \mathrm{C}$, respectively. After reaching the maximum point, the storage modulus values of the NFC and MFC films decreased with increasing the temperature up to $230^{\circ} \mathrm{C}$.

Figure 6 showed that the storage modulus of the NFC and MFC films for the temperature of $30^{\circ} \mathrm{C}$ were observed to be 6,04 GPa and 2,82 GPa respectively. The maximum storage modulus values for $\mathrm{NFC}$ and MFC were 7,68 GPa and 3,82 GPa respectively.

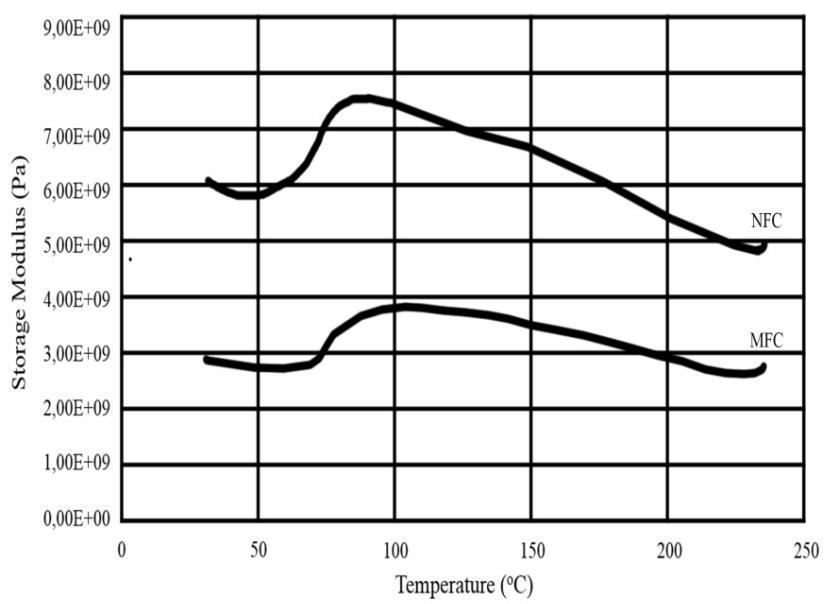

Figure 6. Storage modulus results of the nano- or micro films.

\section{DISCUSSIONS}

Yield, kappa and viscosity (degree of polymerization of the cellulose) analyses

The yield, kappa and viscosity values of un/bleached kraft pulp are shown in Table 1. Ayata (2008) 
utilized the same wood species and pulping conditions, found similar yield, kappa and viscosity for the unbleached kraft pulp. Bleaching removed the lignin from the structure and it was noted that the kappa number and viscosity values decreased when the pulp was bleached in this study. A significant decrease in viscosity and kappa was observed when pulp was bleached with chlorine dioxide. This finding could be explained by lignin delignification and polysaccharide degradation during bleaching stage (Barroca et al. 2001). The $\mathrm{NaOH}$ (E) used in the bleaching stage in addition extracted some lignin as well as low molecular weight carbohydrates and consequently diminished the total yield. On the other hand, a slight increase in pulp viscosity during E stage bleaching $(5,60 \mathrm{cP})$ was observed in this study. Similar finding was observed earlier by Islam (2004). This finding could be explained by the removal of some low molecular weight materials from the structure.

\section{Chemical properties}

\section{HPLC analyses}

The chemical composition of wood and un/bleached pulps were shown in Table 2. The chemical compositions of wood determined in this study were comparable with the findings of Moussaouiti et al. (2012). The lignin, glucan and xylan solubilizations were found to be $97,7 \% ; 31,2 \%$ and $31,6 \%$ (o.d. chip) for the bleached pulp, respectively. The proportional increase in glucan content for both un/ bleached kraft pulps was explained by the lignin delignification. The kraft pulp had 15,3\% xylan and bleaching slightly decreased the xylan content. Removal of xylan with lignin could be due to the lignin carbohydrate complexes (LCC).

The bleached kraft pulp was first mechanically pretreated and the treated samples had slightly lower glucan and xylan contents. Chen et al. (2013) also observed similar results. It was shown that the enzyme had minor effect on glucan degradation (Table 3). The enzyme preserved the xylan in the structure diminished the cell wall cohesion and resulted in easier cell wall delamination (Kolakovic 2013). This in addition prevented the blocking in the homogenizer (Pääkko et al. 2007). Consequently, the enzyme concentration (100 AXU/g) applied in this study removed up to 5,37\% (o.d. bleached kraft pulp) of the xylan. The sample was then mechanically pretreated and the results showed almost no xylan or glucan degradation. On the other hand, when MFC and NFC were produced the samples had slightly lower amount of xylan and glucan (Virtanen et al. 2014, Zhang 2013).

\section{FTIR analyses}

$\mathrm{O}-\mathrm{H}$ stretching peaks observed at $3328 \mathrm{~cm}^{-1}$ indicated the successive pretreatments of MFC and NFC production which led gradual decrease in $\mathrm{O}-\mathrm{H}$ peak intensity when compared to bleached kraft pulp (Mandal and Chakrabaty 2011, Ang et al. 2012, Poletto et al. 2014). This finding implied that pretreatments to produce MFC and NFC caused insignificant cellulose disintegration as well more specific surface area in the samples (Abraham et al. 2013, Ng et al. 2015, Popescu et al. 2011, Jiang and Hsieah 2013). The progressively decreasing peaks observed at $1336 \mathrm{~cm}^{-1}$ had the similar reaction pattern alike O-H stretching peaks (Jonoobi et al. 2009). Lignin content in this study have not been detected at $1740 \mathrm{~cm}^{-1}, 1509 \mathrm{~cm}^{-1}$ and $1463 \mathrm{~cm}^{-1}$ vibrations (Abraham et al. 2013, Mandal and Chakrabarty 2011). It was seem that these vibrations remained limit of detection after FTIR analysis due to the fact that suspensions having minor lignin moieties. The peak intensity observed at $1033 \mathrm{~cm}^{-1}\left(\mathrm{C}_{1}-\mathrm{O}-\mathrm{C}_{4}\right)$ decreased and this finding showed the degradation of the cellulose chains during the MFC and NFC production (Proniewicz et al. 2001, Oh et al. 2005).

TCI is closely related to the crystallinity and the degree of the intermolecular bonds (Carrilo et al. 2004, Poletto et al. 2014). LOI has been used as an evidence for the presence of cellulose I in the cellulosic materials (Ang et al. 2012, Mandal and Chakrabarty 2011). Besides, cellulose II formation was observed in amorph structure after pretreatments (Oh et al. 2005). LOI and TCI were correlated with the overal degree of cellulose order (Poletto et al. 2014, Oh et al. 2005). Results showed that bleached kraft pulp had the highest TCI and LOI values revealing the highest crystallinity compared to MFC and NFC. On the other hand, MFC and NFC with lower cellulose infrared crystallinity indicated a larger number of amorphous domains in their structutre. This finding was also supported with ${ }^{13} \mathrm{C}-\mathrm{NMR}(46,2 \mathrm{ppm})$, which was substantiated with C6 peaks in the amorphous domain. The disorder 
of cellulosic structure may be due to the deformation vibration of $\beta$-glycosidic linkages and hydrogen bond rearrangements.

\section{${ }^{13}$ C-NMR analyses}

The chemical shifts were generally observed in the range of 110-60 ppm (Newman 2004, Park et al. 2009). In this study, chemical shifts were observed at $90-45 \mathrm{ppm}$. This is attributed to the packing effect of the supramolecular structures stemming from chemical reactions, physical processes, etc. (Zuckerstätter et al. 2009).

The intensity of the peaks was highest for the bleached kraft pulp compared to MFC and NFC. Results showed that pretreatments to produce MFC and NFC caused some structural deformations in glucose units (Duchesne et al. 2001, Newman 2004).

Crystalline and amorphous domains were observed as separate doubled-collateral peaks at 63-76 ppm and 45-51 ppm (Maheswari et al. 2012, Park et al. 2009). Exception was only observed in C6 for the bleached kraft pulp. These indicated the alterations in samples crystallinity which was also verified by TCI and LOI values.

C2, C3 and C5 peaks were observed at around 61-53 ppm. Results showed that pretreatments had no significant effect and the peaks of bleached kraft pulp, MFC and NFC were almost identical.

\section{Rheological properties}

The viscosity of the suspensions decreased with the increase in the shear rate. This might be due to the shear thinning behavior of the suspensions. Because, at the beginning, MFC and NFC suspensions had a tendency to become unstable due to flocculation and entangled thicker fibers in the network. Later, this flocculation and entanglement started to disappear with applied shear rate. Therefore, shear thinning behavior was observed in the suspensions. Consequently, the suspensions are evaluated as pseudoplastic materials in this study. The suspensions were viscous under normal conditions, but the viscosity of the suspensions was decreased when the suspension was stressed and the shearing forces were removed (Berca and Navard 2000, Pääkko et al. 2007).

To obtain MFC and NFC, processes of enzymatic and mechanical pretreatments followed by homogenization significantly diminished the viscosity of the suspensions. This decrease could be explained by the lower floc size, higher narrow size distribution, gradual breaking of 3D network as well as Einstein coefficient: higher length to diameter ratio (Dufresne 2012, Jia et al. 2014).

\section{Morphological (Structural) properties}

SEM images of the bleached kraft pulp, MFC and NFC was shown in Figure 4. Mechanical refining swells the fibers and creates damaged zones, which enhances the enzymatic activity (Pääkko et al. 2007). Enzymatic pretreatments improve the fibrillation and results in efficient homogenization.

Trials to produce MFC and NFC from mechanically refined pulp (without enzymatic pretreatment) caused blockage in the constriction chambers of the homogenizer. SEM images for these samples showed a large fraction of intact fibers in the structure. Applying only mechanical shearing causes less fiber swelling which damages fibrillar structure. In addition, the process required excessive energy and was therefore not feasible to produce well-defined nanoscale cellulose elements. On the other hand, strong acid hydrolysis is an aggressive process and yields low aspect ratio cellulose elements (Pääkko et al. 2007). Consequently, less aggressive enzymatic hydrolysis (xylanase endo-1,4-) was applied in this study. According to the HPLC results, the highest xylose-containing pulp (concentration of 100 $\mathrm{AXU} / \mathrm{g}$ ) was selected as the optimum for xylanase endo-1,4- pretreatment, and thus resulted in easier MFC and NFC production. Easier production could be explained by higher hemicellulose content of the sample which decreased the cell wall cohesion and made cell wall delamination easier (Kolakovic 2013, Pääkko et al. 2007). 
When enzymatically hydrolyzed pulps were mechanically refined, the efficiency of homogenization was improved and intense cell wall delamination was observed. The pass of the material once through the $200 \mu \mathrm{m}$ chamber (14000 psi) was certainly enough to produce MFC. This finding could be due to the samples having higher hemicellulose content causing better fiber swelling.

Fairly homogeneous NFC was produced in this study and cellulosic nanofibers had an average length of $3820 \pm 170 \mathrm{~nm}$ and a width of $35 \pm 12 \mathrm{~nm}$. NFC was generated with the average aspect ratio of $115 \pm 35$. Moon et al. (2011) produced NFC with almost similar method to this study having a diameter of 4 to $10 \mathrm{~nm}$ and length of several micrometers with the aspect ratio $(>100)$. Zimmermann et al. (2010) obtained nanofibrils from mechanically pretreated sulfite pulp after passing material from the microfluidizer. The width of the nanofibrils was less than $100 \mathrm{~nm}$ and they had a high length ratio. On the other hand, super-grinding produced nanofibrils having a width of $20-90 \mathrm{~nm}$ (Taniguchi and Okamura 1998). It was concluded that fibers can be degraded to nanoscale by exposing them to shearing stresses in the longitudinal fiber axis. It seems that microfluidizers and super-grinders have a similar effect and nanofibrils of a similar size were produced with microfluidizers in this study. In the case of using sulfite pulp, when the fibers were mechanically and enzymatically pretreated, Ankerfors et al. (2009) obtained nanofibrils with a width of 10-20 nm using microfludizers. The lower size could be due to the pulp type having a higher hemicellulose content, as compared to the kraft pulp utilized in this study. Leitner et al. (2007) used an APV Gaulin laboratory-type homogenizator (10-15 pass at 300 bars) and produced 30-100 nm-width nanofibers from mechanically pretreated sugar cane pulp processed with chemical methods.

\section{Thermal analysis}

The first degradation could be attributed to losses of the moisture and low molecular weight compounds. Water was found as chemisorbed, loosely bound and free. The bound water in the structure is also observed in FTIR spectra $\left(1650 \mathrm{~cm}^{-1}\right)$ (Mandal and Chakrabarty 2011). Of the samples, bleached kraft pulp had the highest moisture content.

A significant weight loss observed at about $320-400{ }^{\circ} \mathrm{C}$ could be due to the cellulose and hemicellulose decomposition (Luduena et al. 2011). Also this mass loss revealed that cellulose polymer degradation (Zoppi and Gonçalves 2002).

The highest degradation temperature of $338^{\circ} \mathrm{C}$ was needed for the most crystalline bleached kraft pulp (Kim et al. 2010). The calculated TCI and LOI values and ${ }^{13} \mathrm{C}-\mathrm{NMR}$ results of C6 peaks also supported the thermal stability observations in this study. Pretreatments to produce MFC and NFC caused less ordered and packed cellulose regions as well as shorter fiber dimensions that resulted in lower thermal degradation (Jiang and Hsieh 2013, Shimazaki et al. 2007). Up to $650{ }^{\circ} \mathrm{C}$, additional decomposition of hemicellulose and lignin was observed (Yang et al. 2007). The highest solid residue was observed for the NFC and the result may be due to the presence of more stable cellulose I in the sample (Mandal and Chakrabarty 2011, Spiridon et al. 2010).

\section{Dynamic mechanical thermal analysis (DMTA) of nano/micro films}

The initial and maximum storage modulus values of the NFC and MFC films were improved by $114 \%$ and $101 \%$, respectively. The storage modulus values of the films were 4,96 GPa and 2,66 $\mathrm{GPa}$ at temperature of $235^{\circ} \mathrm{C}$, respectively. The storage modulus of the NFC film was enhanced by $86 \%$ at high temperatures. The results clearly showed that overall performance or high temperature performance of the NFC was higher when compared to MFC. Composite materials having NFC have higher mechanical performance than composite materials having MFC (Arjmandi et al. 2015). Similar findings were obtained by Honorato et al. (2015) who determined the storage modulus (7,20 GPa) of the TEMPO-oxidized NFC films. Bulota (2012), who developed TEMPO-oxidized NFC films concluded that increase in the storage modulus of the samples were observed when NFC content was increased. 


\section{CONCLUSIONS}

Biopolymers are of significant application for industry. In this study, fairly homogeneous NFC gel $(3820 \mathrm{~nm} / 35 \mathrm{~nm} / 115$; length/width/aspect ratio) was prepared. The enzyme xylanase endo-1,4effectively degraded the glucan and xylan in the structure of the kraft pulp as well as improving the fibrillation. This circumstance paved the way efficient homogenization. Molecular structure of the MFC and NFC exhibited minor differences compared to kraft pulp and also different crystallinity was observed in the samples. Lower crystallinity value was observed in the NFC. Shear thinning behavior was observed in all samples, while the NFC had the lowest viscosity value. NFC and MFC films were successfully fabricated as well. Storage moduli of the MFC and NFC films revealed similar trend and the NFC film gave the highest thermomechanical properties over the room temperature.

\section{ACKNOWLEDGEMENTS}

This work was supported by the Scientific and Technological Research Council of Turkey (TUBITAK Project Number: 114O022).

\section{REFERENCES}

Abraham, E.; Deepa, B.; Pothen, L.A.; Cintil, J.; Thomas, S.; John, M.J.; Anandjiwala, R.; Narine, S. S. 2013. Environmental friendly method for the extraction of coir fibre and isolation of nanofibre. Carbohydr Polym 92(2):1477-1483.

Agbor, V. B.; Cicek, N.; Sparling, R.; Berlin, A.; Levin, D.B. 2011. Biomass pretreatment: fundamentals toward application. Biotechnol Adv 29(6):675-685.

Ang, T.N.; Ngoh, G.C.; Chua, A.S.M.; Lee, M.G. 2012. Elucidation of the effect of ionic liquid pretreatment on rice husk via structural analyses. Biotechnol Biofuels 5(1):67-77.

Ankerfors, M.; Lindström, T.; Henriksson, G. 2009. Method for the manufacture of microfibrillated cellulose. US Pat. 20090221812 A1.

Arjmandi, R.; Hassan, A.; Eichhorn, S.; Mohamad Haafiz, M.K.; Zakaria, Z.; Tanjung, F. 2015. Enhanced ductility and tensile properties of hybrid montmorillonite/cellulose nanowhiskers reinforced polylactic acid nanocomposites. J Mater Sci 50(8):3118-3130.

Ayata, U. 2008. A research of eucalyptus (Eucalyptus camaldulensis and Eucalyptus grandis) wood properties and their use in the paper industry. Master Thesis, Science Institute of Kahramanmaraş Sütçü İmam University, Kahramanmaraş, Turkey.

Barroca, M.J.M.C.; Simoes, R.M.S.; Castro, J.A.A.M. 2001. Kinetics of chlorine dioxide delignification of a hardwood pulp. Appita J 54:190-195.

Berca, M.; Navard, P. 2000. Shear dynamics of aqueous suspensions of celluose whiskeys. Macromolecules 33(16):6011-6016.

Bismarck, A.; Mishra, S.; Lampke, T. 2005. Plant fibres as reinforcement for green composites Natural Fibres, Biopolymers, and Biocomposites. Ed: Mohanty, A. K.; Misra, M.; Drzal, L. T. (Boca Raton: CRC Press) p 37-108. 
Bulota, M. 2012. Deformation and fracture mechanisms in nanocellulose reinforced composites. $\mathrm{PhD}$ Thesis, Aalto University, School of Chemical Technology, Department of Forest Products Technology, Helsinki, Finland.

Carrilo, F.; Colom, X.; Sunol, J.; Saurina, J. 2004. Structural FTIR analysis and thermal characterization of lyocell and viscose-type fibers. Eur Polym J 40(9):2229-2234.

Chang, X.F.; Olson, J.A.; Beatson, R.P. 2012. A comparison between the effects of ozone and alkaline peroxide treatments on TMP properties and subsequent low consistency refining. BioRes 7(1):99-111.

Chen, X.; Kuhn, E.; Wang, W.; Park, S.; Flanegan, K.; Trass, O.; Tenlep, L.; Tao, L.; Tucker, M. 2013. Comparison of different mechanical refining technologies on the enzymatic digestibility of low severity acid pretreated corn stover. Bioresour Technol 147:401-408.

Dri, F.L.; Hector, L. G.; Moon, R. J.; Zavattieri, P.D. 2013. Anisotropy of the elastic properties of crystalline cellulose I $\beta$ from first principles density functional theory with Van der Waals interactions. Cellulose 20(6): 2703-2718.

Duchesne, I.; Hult, E.; Molin, U.; Daniel, G.; Iversen, T.; Lennholm, H. 2001. The influence of hemicellulose on fibril aggregation of kraft pulp fibres as revealed by FE-SEM and CP/MAS 13C-NMR. Cellulose 8(2):103-101.

Dufresne, A. 2012. Nanocellulose: From nature to high performance tailored materials. Grenoble: Walter de Gruyter, (Chapter 6).

Habibi, Y.; Lucia, L.A.; Rojas, O.J. 2010. Cellulose nanocrystals: chemistry, self-assembly, and applications. Chem Rev 110(6):3479-3500

Hettrich, K.; Pinnow, M.; Volkert, B.; Passauer, L.; Fischer, S. 2014. Novel aspects of nanocellulose. Cellulose 21(4):2479-2488.

Honorato, C.; Kumar, V.; Liu, J.; Koivula, H.; Xu, C. 2015. Transparent nanocellulose pigment composite films. J Mater Sci 50(22):7343-7352.

Islam, M.N. 2004. Effect of chemical charges in cooking and their effectiveness on pulp bleaching. $J$ Sci Ind Res 63:522-526.

Jia, X.; Chen, Y.; Shi, C.; Ye, Y.; Abid, M.; Jabbar, S.; Wang, P.; Zeng, X.; Wu, T. 2014. Rheological properties of an amorphous cellulose suspension. Food Hydrocolloid 39:27-33.

Jiang, F.; Hsieh, Y. L. 2013. Chemically and mechanically isolated nanocellulose and their selfassembled structures. Carbohydr Polym 95(1):32-40.

Jonoobi, M.; Niska, K.O.; Harun, J.; Shakeri, A.; Misra, M. 2009. Chemical composition, crystallinity, and thermal degradation of bleached and unbleached kenaf bast (Hibiscus cannabinus) pulp and nanofibers. BioRes4:626-639.

Khalil, H.P.S.A.; Bhat, A.H.; Yusra, A.F.I. 2012. Green composites from sustainable cellulose nanofibrils: A review. Carbohydr Polym 87(2):963-979.

Kim, U.J.; Eom, S. H.; Wada, M. 2010. Thermal decomposition native cellulose: Influence on crystallite size. Polym Degrad Stab 95(5):778-781.

Kolakovic, R. 2013. Nanofibrillar cellulose in drug delivery. PhD Thesis. Division of Pharmaceutical Technology, Faculty of Pharmacy, University of Helsinki, Helsinki, Finland. 
Kord, B.; Malekian, B.; Yousefi, H.; Najafi, A. 2016. Preparation and characterization of nanofibrillated Cellulose/Poly (Vinyl Alcohol) composite films. Maderas Cienc Tecnol 18(4): 743-752.

Lavoine, N.; Desloges, I.; Dufresne, A.; Bras, J. 2012. Microfibrillated cellulose-its barrier properties and applications in cellulosic materials: A review. Carbohydr Polym 90(2):735-764.

Lee, H.V.; Hamid, S.B.A.; Zain, S.K. 2014. Conversion of lignocellulosic biomass to nanocellulose: structure and chemical process. Scientific World J 2014:1-20.

Leitner, J.; Hinterstoisser, B.; Wastyn, M.; Keckes, J.; Gindl, W. 2007. Sugar beet cellulose nanofibril-reinforced composites. Cellulose 14(5):419-425.

Li, W.; Wang, R.; Liu, S. 2011. Nanocrystalline cellulose prepared from softwood kraft pulp via ultrasonic-assisted acid hydrolysis. BioRes 6:4271-4281.

Luduena, L.; Fasce, D.; Alvarez, A.; Stefani, I. P. 2011. Nanocellulose from rice husk following alkaline treatment to remove silica. BioRes 6(2):1440-1453.

Maheswari, C.U.; Reddy, K.O.; Muzenda, E.; Guduri, B.R.; Rajulu, A.V. 2012. Extraction and characterization of cellulose microfibrils from agricultural residue-Cocosnucifera L.. Biomass Bioenerg 46:555-563.

Mandal, A.; Chakrabrty, D. 2011. Isolation of nanocellulose from waste sugarcane bagasse and its characterization. Carbohydr Polym 86(3):1291-1299.

Moon, R.J.; Martini, A.; Nairn, J.; Simonsen, J.; Youngblood, J. 2011. Cellulose nanomaterials review: Structure, properties and nanocomposites. Chem Soc Rev 40(7):3941-3994.

Moussaouiti, M.E.; Barcha, B.; Alves, E.F.; Francis, R.C. 2012. Kraft pulping characteristics of three Moroccan eucalypti. Part 1. Physical and chemical properties of woods and pulps. BioRes $7(2): 1558-1568$.

Newman, R.H. 2004. Carbon-13 NMR evidence for cocrystallization of cellulose as a mechanism for hornification of bleasched kraft pulp. Cellulose 11(1):45-52.

Ng, H. M.; Sin, L. T.; Tee, T. T.; Bee, S.T.; Hui, D.; Low, C.Y.; Rahmat, A.R. 2015. Extraction of cellulose nanocrystals from plant sources for application as reinforcing agent in polymers. Compos Part B Eng 75:176-200.

Oh, S. Y.; Yoo, D. I.; Shin, Y.; Seo, G. 2005. FTIR analysis of cellulose treated with sodium hydroxide and carbon dioxide. Carbohydr Res 340(3):417-428.

Pääkko, M.; Ankerfors, M.; Kosonen, H.; Nykänen,A.; Ahola, S.; Österberg, M.; Ruokolainen, J.; Laine, J.; Larsson, P.T.; Ikkala, O.; Lindström, T. 2007. Enzymatic hydrolysis combined with mechanical shearing and high-pressure homogenization for nanoscale cellulose fibrils and strong gels. Biomacromolecules 8(6):1934-1941.

Park, S.; Johnson, D.K.; Claudia, I.I.; Parilla, P.A.; Davis, M.F. 2009. Measuring the crystallinity index of cellulose by solid state 13C nuclear magnetic resonance. Cellulose 16(4):641-647.

Pérez, J.; Muñoz-Dorado, J.; De La Rubia, T.; Martínez, J. 2002. Biodegradation and biological treatments of cellulose, hemicellulose and lignin: An overview. Int Microbiol 5(2):53-63.

Poletto, M.; Pistor, V.; Zattera, A.J. 2014. Structural characteristics and thermal properties of native cellulose. Materials 7:6105-6119. 
Popescu, M.C.; Popescu, C. M.; Lisa, G.; Sakata, Y. 2011. Evaluation of morphological and chemical aspects of different wood species by spectroscopy and thermal methods. J Mol Struct 988(13):65-72.

Poyraz, B.; Tozluoğlu, A.; Candan, Z.; Demir, A.; Yavuz, M. 2017. Influence of PVA and silica on chemical, thermo-mechanical and electrical properties of Celluclast-treated nanofibrillated cellulose composites. Int J Biol Macromol 104: 384-392.

Proniewicz, L.M.; Paluszkiewicz, C.; Weselucha-Birczynska, A.; Majcherczyk, H.; Baranski, A.; Konieczna, A. 2001. FT-IR and FT-Raman study hydrothermally degradated cellulose. $J \mathrm{Mol}$ Structure 596(1-3):163-69.

Saito, T.; Kimura, S.; Nishiyama, Y.; Isogai, A. 2007. Cellulose nanofibers prepared by TEMPOmediated oxidation of native cellulose. Biomacromolecules8(8):2485-2491.

Shimazaki, Y.; Miyazaki, Y.; Takezawa, Y.; Nogi, M.; Abe, K.; Ifuku, S.; Yano, H. 2007. Excellent thermal conductivity of transparent cellulose nanofiber/epoxy resin nanocomposites. Biomacromolecules 8(9):2976-2978.

Siro, I.; Plackett, D. 2010. Microfibrillated cellulose and new nanocomposite materials: A review. Cellulose 17(3):459-494.

Sluiter, A.; Hames, B.; Ruiz, R.; Scarlata, C.; Sluiter, J.; Templeton, D. 2004. Determination of structural carbohydrates and lignin in biomass. Biomass Analysis Technology Team Laboratory Analytical Procedures. National Renewable Research Laboratory, Golden, CO, USA.

Spence, K. L.; Venditti, R. A.; Rojas O. J.; Habibi, Y.; Pawlak, J. J. 2011. A comparative study of energy consumption and physical properties of microfibrillated cellulose produced by different processing methods. Cellulose 18(4):1097-1111.

Spiridon, I.; Teaca, C.A.; Bodirlau, R. 2010. Structural changes evidenced by FTIR spectroscopy in cellulosic materials after pre-treatment with ionic liquid and enzymatic hydrolysis. BioRes 6(1):400413.

Syverud, K.; Stenius, P. 2008. Strength and barrier properties of MFC films. Cellulose 16:75-85.

Taniguchi, T.; Okamura, K. 1998. New films produced from microfibrillated natural fibers. Polym Int 47(3):291-294.

Viana, L. C.; De Muniz, G. I. B.; Hein, P. R. G.; Magalhães, W. L. E.; Carneiro, M. E. 2016. NIR spectroscopy can evaluate the crystallinity and the tensile and burst strengths of nanocellulosic films. Maderas Cienc Tecnol 18(3): 493-504.

Virtanen, S.; Vartianen, J.; Setala, H.; Tammelin, T.; Vuoti, S. 2014. Modified nanofibrillated cellulose-polyvinyl alcohol films with improved mechanical performance. $R S C \operatorname{Adv} 4: 11343-11350$.

Yang, H.; Yan, R.; Chen, H.; Lee, D. H.; Zheng, C. 2007. Characteristics of hemicellulose, cellulose and lignin pyrolysis. Fuel 86(12-13):1781-1788.

Zhang, Z. 2013. Chemical functionalization of nanofibrillated cellulose by alkoxysilanes: application to the elaboration of composites and foams. PhD Thesis. Université Bordeaux, Bordeaux, France.

Zimmermann, T.; Bordeanu, N.; Strub, E. 2010. Properties of nanofibrillated cellulose from different raw materials and its reinforcement potential. Carbohydr Polym 79:1086-1093. 
Zuckerstätter, G.; Schild, G.; Wollboldt, P.; Röder, T.; Weber, H.; Sixta, H. 2009. The elucidation of cellulose supramolecular structure by 13C CP-MAS NMR. LenzingerBerichte 87:38-46. 